\title{
Sickle cell trait, exertion-related death and confounded estimates
}

\author{
Steven D Stovitz, ${ }^{1}$ Ian Shrier ${ }^{2}$
}

Sickle cell trait (SCT) has historically been thought of as a benign condition. However, there has been increasing recognition that, in athletes, SCT is associated with an elevated risk for exertion-related death (ERD). ${ }^{1}$ With the hope to minimise future tragedies, Harmon et $a l^{2}$ sought to quantify the association of SCT and ERD. They looked at data compiled on nearly two million collegiate 'athlete-years' between 2004 and 2008. Since the risk associated with SCT was highest among Division 1 (D1) football players, the authors elected to focus on that group. Their highlighted conclusions, 'Sickle cell trait associated with a RR of death of 37 times...', are now being referenced in discussions regarding SCT testing. ${ }^{3}$ Others may have concerns about generalising results from D1 athletes to all athletes or lack of discussion about the small number of deaths (from a statistical standpoint) and thus uncertainty surrounding the results. Our concern is that the conclusions based on combining data from all race/ethnicities are not meaningful

\footnotetext{
${ }^{1}$ Department of Family Medicine and Community Health, and Intercollegiate Athletic Department, University of Minnesota, Minneapolis, Minnesota, USA; ${ }^{2}$ Centre for Clinical Epidemiology, Lady Davis Institute for Medical Research, Jewish General Hospital, McGill University, Montreal, Canada
}

Correspondence to Dr Steven D Stovitz, Department of Family Medicine and Community Health, and Intercollegiate Athletic Department, University of Minnesota, 717 Delaware St. SE, Minneapolis, MN 55414, USA;

sstovitz@umphysicians.umn.edu

SDS and IS contributed equally. because of confounding bias secondary to race/ethnicity.

Among the D1 footballers, the researchers found 1 ERD in every 827 athlete-years in those who had SCT. Although the issue of race/ethnicity is an uncomfortable topic, given the known association of SCT and African-American race/ethnicity (referred to as 'Black' in the article ${ }^{2}$ ), the researchers wisely analsed the data separately for 'Black' athletes and for 'non-Black' athletes. However, they subsequently combined the information from 'all ethnicities' and in their conclusions highlighted the relative risk (RR) of SCT from the combined data. Combining the data introduced confounding by race/ethnicity and biased the association of SCT with ERD. Whether biological effect modification was also present cannot be evaluated because the small number of events makes any stratumspecific estimate unreliable.

Table 1 highlights the pertinent numbers from the analysis. ${ }^{2}$ Among the Black D1 football players, SCT was associated with a 22-fold higher risk of ERD. However, among the non-Black players, only one ERD occurred, and that was in an athlete who did not have SCT. It is therefore impossible to conclude that SCT is a risk factor in the non-Black players. As seen in table 1 under the heading of 'All Ethnicities', when the numbers within all race/ethnicity strata are combined, it now appears that those with SCT are at a 37 -fold higher risk. The reason to question the increase in RR from 22 (in the Black athletes) to 37 when adding athletes who are not at risk of ERD is because the results based on combining the data from all D1 footballer players are confounded by race/ethnicity.

Table 1 Division 1 football players

\begin{tabular}{|c|c|c|c|c|c|}
\hline & $\begin{array}{l}\text { Exertional } \\
\text { deaths }\end{array}$ & $\begin{array}{l}\text { Number of } \\
\text { participants }\end{array}$ & $\begin{array}{l}\text { Risk of death } \\
\text { per } 1000 \\
\text { athlete-years* }\end{array}$ & $\begin{array}{l}\text { Risk difference } \\
\text { per } 1000 \\
\text { athlete-yearst }\end{array}$ & $\begin{array}{l}\text { Relative } \\
\text { risk }\end{array}$ \\
\hline \multicolumn{6}{|l|}{ All ethnicities } \\
\hline SCT positive & 5 & 4134 & 1.210 & 1.177 & $37 \S$ \\
\hline SCT negative & 4 & 123313 & 0.033 & & \\
\hline Total & 9 & 126447 & 0.071 & & \\
\hline \multicolumn{6}{|l|}{ Black athletes } \\
\hline SCT positive & 5 & 4024 & 1.243 & 1.186 & 22 \\
\hline SCT negative & 3 & 53464 & 0.056 & & \\
\hline Total & 8 & 57488 & 0.139 & & \\
\hline \multicolumn{6}{|c|}{ Non-black athletes } \\
\hline SCT positive & 0 & 110 & 0 & -0.015 & 0 \\
\hline SCT negative & 1 & 68849 & 0.015 & & \\
\hline Total & 1 & 68959 & 0.015 & & \\
\hline
\end{tabular}

* Risk=Deaths/number of athlete-years.

†Risk difference $=$ (Risk in SCT positive $)$ - (Risk in SCT negative) .

‡Relative risk=(Risk in SCT positive)/(Risk in SCT negative).

$\S$ We do not recommend making this calculation. See text for explanation.

SCT, sickle cell trait. 


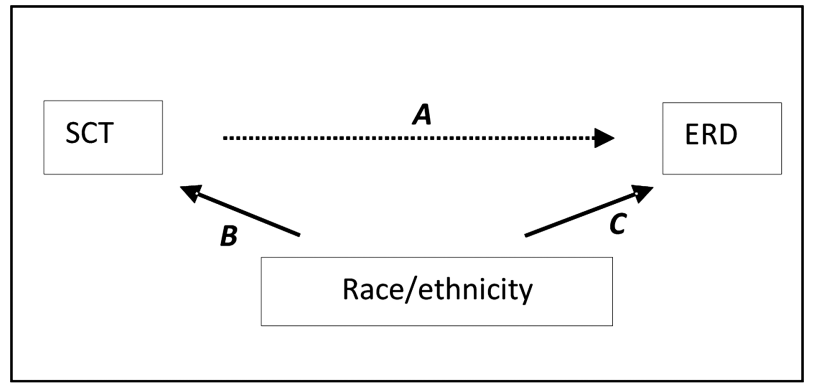

$\mathrm{SCT}=$ Sickle cell trait

$\mathrm{ERD}=$ Exertion-related death

Figure 1 Directed acyclic graph depicting that race/ethnicity is a common cause of both sickle cell trait and exertion-related death, and thus confounds the research question.

Confounding may occur when there is a cause (here, Black race/ethnicity) of both the independent variable, that is, the 'exposure' (here, SCT), and the dependent variable, that is, the 'outcome' (here, ERD). As illustrated in the directed acyclic graph in figure 1 , the dotted line, 'A', refers to the research question; namely, what is the direct effect of SCT on ERD? Since those with SCT are clearly more likely to be of Black race/ethnicity, and those with suffered ERD were, likewise, clearly more likely to be of Black race/ethnicity (note that this is regardless of SCT status), figure 1 contains the solid lines B and $\mathrm{C}$, respectively. When the exposure and outcome share a cause, the true causal effect of the exposure on the outcome cannot be assessed without appropriate adjustment (eg, stratification) on the shared cause.

The effect of confounding in this analysis may be made more explicit by examining the absolute risks shown in table 1 . Note that the risk of death in those with SCT is essentially the same when looking at 'all ethnicities' or when looking only at 'Black athletes' (1.210 vs $1.243 / 1000$ athlete-years, respectively). However, the risk of death in those without SCT is, relatively, much lower when considering 'all ethnicities', than when considering 'Black athletes' only $(0.033$ vs $0.056 / 1000$ athlete-years, respectively). This results in a dramatic, 1.7-fold, increase in the RR from 22 to 37 . To further clarify the effect of confounding in this particular case, consider this: SCT was not a risk factor for death in the non-Blacks (there were no deaths in the non-Blacks who had SCT), yet if the study included twice the number of non-Blacks (ie, 137918 rather than 68 959), and if the risks in all groups remained the same as those reported, the calculated RR among all D1 football players would now be 45 !

Ultimately the debate about sickle cell screening should not be based on RRs, but rather on the absolute number of athletes that would be identified and saved by a policy intervention, the ramifications of that policy and value judgments. In coming to a decision, consideration must be given to the burdens placed on the athletes who test positive; such as altered practices, medications and career prospects. We again emphasise the role of value judgments; there are no absolute rules, and treatment differences based on race/ethnicities should be instituted only when unequivocally justified. The study by Harmon et $a l^{2}$ shows that SCT is a major risk factor for ERD in Black collegiate athletes. An accompanying editorial suggests 'targeted screening of high risk groups.' 3 Whether the current data support a policy based partially on race/ ethnicity is one such value judgment that requires careful evaluation, and underscores the need to focus on unbiased causal estimates whenever possible.

Acknowledgements The authors thank William 0 Roberts, MD, MS and David E Olson, MD for their comments on a preliminary version of this manuscript.

Competing interests None.

Provenance and peer review Not commissioned; externally peer reviewed.

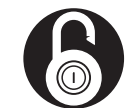

\section{OPEN ACCESS}

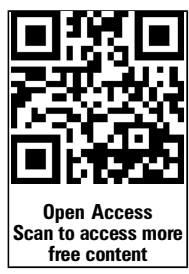

Open Access This is an Open Access article distributed in accordance with the Creative Commons Attribution Non Commercial (CC BY-NC 3.0) license, which permits others to distribute, remix, adapt, build upon this work non-commercially, and license their derivative works on different terms, provided the original work is properly cited and the use is noncommercial. See: http://creativecommons.org/licenses/ by-nc/3.0/

To cite Stovitz SD, Shrier I. Br J Sports Med 2014;48:285-286.

Received 24 July 2012

Revised 14 September 2012

Accepted 9 November 2012

Published Online First 13 December 2012

Br J Sports Med 2014;48:285-286.

doi:10.1136/bjsports-2012-091619

\section{REFERENCES}

1 Eichner ER. Sickle cell considerations in athletes. Clin Sports Med 2011;30:537-49.

2 Harmon KG, Drezner JA, Klossner D, et al. Sickle cell trait associated with a RR of death of 37 times in national collegiate athletic association football athletes: a database with 2 million athlete-years as the denominator. Br J Sports Med 2012;46:325-30.

3 Harmon KG, Drezner JA, Casa DJ. To screen or not to screen for sickle cell trait in American football? $\mathrm{Br} J$ Sports Med 2012;46:158.

4 Eichner ER. American Society of Hematology opposes sickle cell trait screening: a voice from left field. Curr Sports Med Rep 2012;11:106-8. 